\title{
Extinct and endangered species in the vascular plant flora of Strzelce Opolskie
}

\author{
(Southern Poland)
}

\author{
Łukasz Folcik ${ }^{1}$, Andrzej Urbisz ${ }^{1}$ \\ ${ }^{1}$ Department of Plant Systematics, Faculty of Biology and Environmental Protection, University of Silesia, \\ Jagiellońska Str. 28, 40-032 Katowice, Poland \\ E-mail address (corresponding author): lukasz.folcik@vp.pl
}

\begin{abstract}
Symptoms of anthropogenic changes in the vascular plant flora include the spread of some species groups and the extinction of others. Also habitat condition changes (eutrophication, pollution etc.) and biodiversity loss (at a regional, national and even continental scale) should be mentioned. Numerous papers with rare plant species localities and endangered habitats have been published but the extinction processes and scale of this phenomenon in urban areas where environmental conservation is crucial, are not often analysed. The aim of the present study is to estimate species loss in the vascular plant flora of the town Strzelce Opolskie (Chełm, Silesian Upland) on the basis of the floristic literature and botanical surveys carried out from 2011 to 2013. A comparison has been made between the list of species reported up to 1945 and those species currently occurring in the study area. As a result, a list of 99 species included in the red list of plants of Opole and Silesian voivodeships is presented. Among this group, 45 species are not confirmed after 1945. Numerous extinct and endangered species are from families: Orchidaceae (8 species), Cyperaceae $(7$ species), Ranunculaceae $(7$ species $)$ and Lamiaceae (6 species). Strongly represented are species associated with the communities of Festuco-Brometea and QuercoFagetea classes. From the species presented, 18 species are included in "Red List of Vascular Plants of Poland" (MIREK ET AL. 2006). It was found that the extinct species represent about $7 \%$ of Strzelce Opolskie vascular plant flora. It is a focus point for local authorities to protect botanically valuable areas. Actually, the only Miejski Park is under the conservator's protection and there are few individual trees protected due to their age or size.
\end{abstract}

KEY WORDS: flora, vascular plants, red list, Strzelce Opolskie, Silesia

\section{Introduction}

Analyses of extinction processes at the species level are a key issue to be examined by naturalists. Extinction is a natural process but in recent years it has increased rapidly as a result of human activities. Many native species are unable to fit into changing environments. They often show very high habitat specificity to particular biotic and abiotic elements of their environment. In the cultural landscape, urbanisation pressure is the main cause of species loss. As BRIGGS (2010) points, following the theory of natural selection, it is proposed that at each change in human land use, selection favours species having the highest Darwinian fitness (the so called winners) in that particular habitat, while other species of lesser fitness decline (the so called losers). At first, population size decreases, then the general number of localities becomes limited and at last species become extinct.

This paper is an attempt to estimate the changes in the vascular plant flora of Strzelce Opolskie - a town located in Chełm, a mesoregion of the Silesian Upland (Southern Poland) (KoNDRACKI, 1988). Up to 1945 , the major contribution to the floristic studies of this area were made by Germans. Among the botanists who worked on the local flora are WiMMER \& GRABOWSKI $(1827,1829)$, WiMmer (1857), STENZEL (1876), FIEK (1881), SCHUBE $(1903,1904,1911-1925)$, SCHALOW (1931, 1932). After The Second World War numerous papers with rare species localities were published (MichalaK, 1963, 1976, 1981a,b; CiACIURA ET AL., 
1962; MĄDALSKI ET AL. 1963; SENDEK, 1965, 1971, 1989; SzoTKOWSKi, 1969; CELIŃSKI ET AL., 1974; CiACIURA \& KOWAL, 1964). A notable monograph on the flora of the northern part of the Silesian Upland was published in 1974 by KOBIERSKI. In spite of numerous localities of rare and endangered species being given, the extinction processes were not analysed. It is worth noticing that since The War started, up to 1960's no botanical studies were carried out in study area. At the end of $20^{\text {th }}$ century some essays at the national scales began to appear (ZARZYCKI, 1986; ZARZYCKI \& SZELĄG, 1992; ZARZYCKI \& KAŹMIERCZAKOWA, eds., 1993). Some of them have been re-edited in recent years (ZARZYCKI \& KAŹMIERCZAKOWA, eds., 2001; ZARZYCKI \& MIREK, 2006). Also regional scale red books (NoWAK \& SPAєEK, 2002) and lists of vascular plant species were issued (Opole voivodeship - NOWAK ET AL., 2008; Silesian voivodeship - PARUSEL \& URBISZ, eds., 2012). Some valuable information about extinct, rare and endangered species of this region are given in KOZAK ET AL. (2005), URBISZ \& URBISZ (2009), NOWAK (2011a,b), NOWAK ET AL. (2013).

The aim of the present a study is to estimate species loss in the vascular plant flora of the Strzelce Opolskie town, made on the basis of a comparison between the lists of species reported up to 1945 with those species currently occurring in the study area and compare the loss of species with other cities around the World.

\section{Study area}

Strzelce Opolskie ( $50^{\circ} 30^{\prime} \mathrm{N} ; 18^{\circ} 17^{\prime} \mathrm{W}$ ) is a district town located in the eastern part of Opole voivodeship ( $9412 \mathrm{~km}^{2}$ ), southern Poland (Fig. 1). It occupies an area about $31 \mathrm{~km}^{2}$ and is inhabited by more than 18,500 people (GUS, 2012). According to the division of Poland into physical-geographical regions (KONDRACKI, 1988), the town is located in the Chełm Ridge, a mesoregion of the Silesian Uplands.

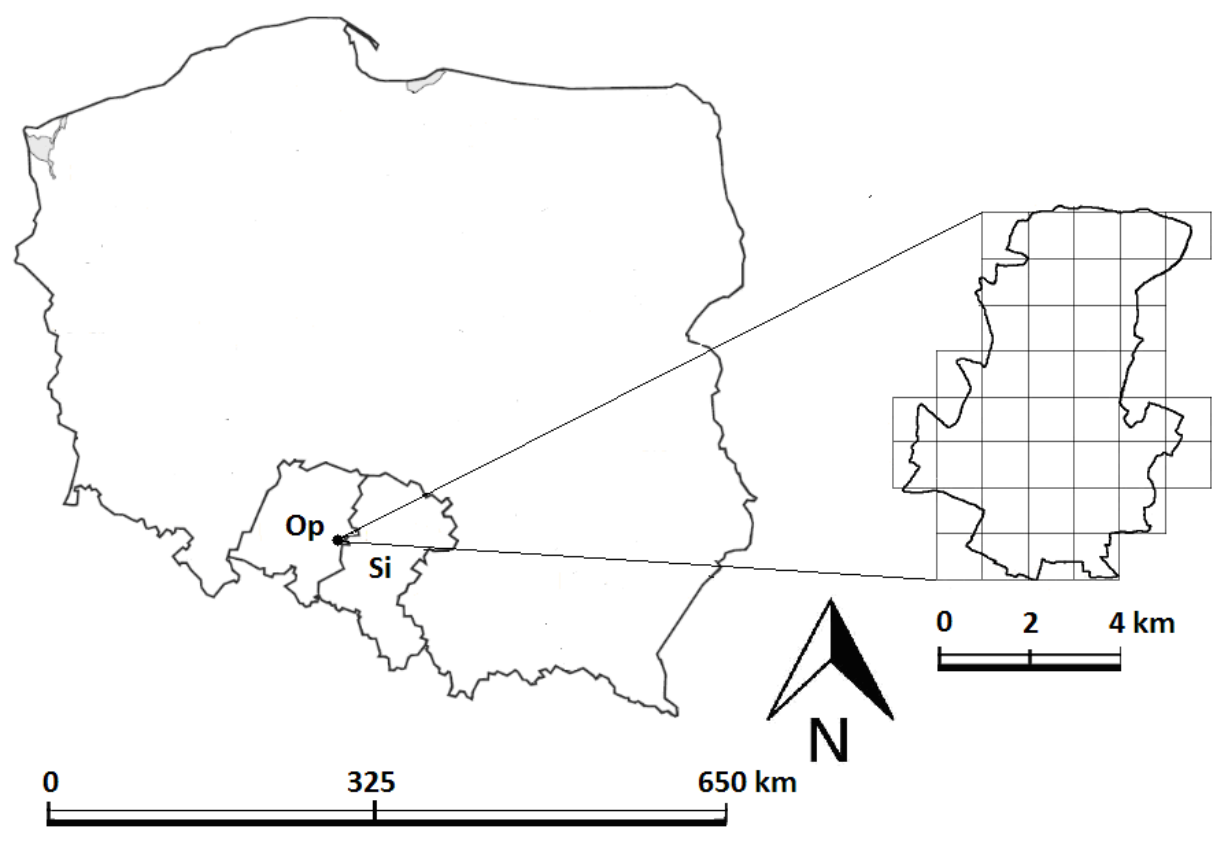

Fig. 1. Map of Strzelce Opolskie , situated in Opole voivodeship (Southern Poland) showing the 1-km grid and the city borders (Op - Opole voivodeship, $\mathrm{Si}$ - Silesian voivodeship)

Strzelce Opolskie originally developed from a trade village which appears to have been already mentioned in documents from the $17^{\text {th }}$ century. The name of the town derived from a Prince's shooters (strzelcy) who hunted in this area. At that time, Strzelce Opolskie was inhabited by farmers cultivating mainly hops and vines and by craftsmen and traders (SMOLEŃ, 1998). In the second half of the $19^{\text {th }}$ century, the town became a major centre for lime and for machinery industries (SZYMANKIEWICZ, 1994). It must be added that up to 1945 the study area was a part of Germany (Groß Strehlitz, Oppeln
Kreis) and botanical studies were carried out only by local scientists, naturalists, teachers and apothecaries. Since the end of The Second World War the town is a part of The Republic of Poland.

The geological structure of the region, according to PAWLAK (1997) comprises of glacial and interglacial Quaternary sediments, Triassic limestone (Lower, Middle and Upper Triassic), dolomites and sandstones. In the soil cover of the town, rendzinas and brown soils can be distinguished. Rarely and at dispersed localities, organic - bog soils are found. The northern, forest 
area is covered with pseudopodsoles. Locally in clays, luvisols have developed (SPAŁEK ET AL., 2007).

In the Strzelce Opolskie area average annual precipitation is about $680 \mathrm{~mm}$ and average annual temperature is $+8.1^{\circ} \mathrm{C}$. The climate is heavily influenced by geographical location, distribution of water-bodies, terrain and type of plant cover (SPAŁEK ET AL., 2007). In terms of meso- and topoclimate, conditions in the study area are harsher than in the central part of Opole voivodeship. This is associated with its location on the edge of the Silesian Upland (PAWLAK, 1997).

Within the administrative boundaries of the town, the river system has almost completely disappeared due to karst processes. There is an outflow directly into the Triassic limestone rock mass. In Strzelce Opolskie there are only anthropogenic water-bodies - the Rybaczówka Lake, ponds in the Park Miejski, reservoirs in limestone quarries and for industrial water treatment.

\section{Materials \& methods}

A list of extinct, rare and endangered species was prepared on the basis of floristic papers (FIEK, 1881; SCHUBE, 1903, 1904, 1919; BRZEZAK, 1928; SCHALOW, 1932; MICHALAK, 1963, 1976, 1981a; KobiersKI, 1974; CiACIURA \& KoWAL, 1974; DAJDOK ET AL., 1998; KOZAK ET AL., 2005; NOWAK, 2005; SPAŁEK ET AL., 2007) and from a field study carried out in 2011-2013 within the administrative boundaries of Strzelce Opolskie. The presence of vascular plant species was recorded systematically within the defined $1 \mathrm{~km}^{2}$ grid-cells according to a system proposed in "Distribution Atlas of Vascular Plants in Poland - ATPOL" (ZAJĄC \& ZAJĄC, 2001). The localities obtained from historical flora lists are not precise and there are no available standardisations to be made (spatial resolution, sampling or inventory methods are not satisfactorily presented).

Species threat categories follow "The Red List of Vascular Plants of Opole Province" (NowAK ET AL., 2008) and "The Red List of Vascular Plant of Silesian voivodeship" (PARUSEL \& URBISZ, eds., 2012).

Species were ranked according to decreasing threat category, starting with extinct species. Separate lists of species confirmed and unconfirmed after 1945 were prepared. A list of species included in the red list of the Silesian voivodeship but not included in the analogous list from Opole voivodeship was prepared. Nomenclature of species follows "Flowering plants and pteridophytes of Poland. A checklist". (MIREK ET AL., 2002). Phytosociological affiliation was adapted from MATUSZKIEWICZ (2008) and ZARZYCKI
ET AL. (2002). The differences between threat categories of the presented species in Opole and Silesian voivodeships and the phyto-sociological spectrum of species classified into each category were prepared as histograms.

\section{Results}

During field studies carried out in 2011-2013 seasons 519 native vascular plant species and established alien plant species (antropophytes) were recorded. A spatial variation in species number within grid cells is shown in Figure 2.

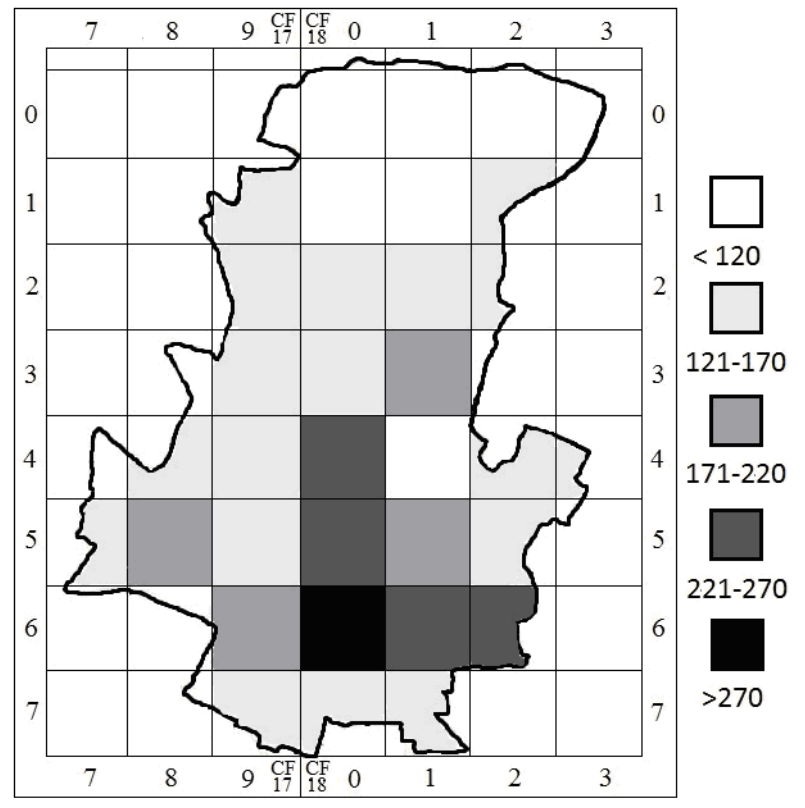

Fig. 2. A spatial variation in number of species within grid cells

In the vascular plant flora of Strzelce Opolskie 45 species have not been confirmed since 1945 (Tab. 1). Among the unconfirmed species there are 6 which are considered to be extinct, 9 critically endangered, 12 endangered, 10 vulnerable, 4 near threatened and 2 species with least concern category in the Opole voivodeship. Another 2 species were not included in the red list of plants of Opole voivodeship.

The next group includes 54 vascular plant species for which occurrence in Strzelce Opolskie has been confirmed since 1945. Among this species, 14 were not included in the red list of vascular plants of Opole voivodeship but were included in the Silesian one (Tab. 2).

In total, of the 99 species placed in the red lists of Opole and Silesian voivodeships which were recorded in Strzelce Opolskie, 45 have not been confirmed since 1945. Most of extinct and endangered species belong to families: Orchidaceae (8 species), Cyperaceae (7 species), Ranunculaceae ( 7 species) and Lamiaceae (6 species). 
In Figure 3 the phytosociological affiliation of species belonging to particular threat categories in Opole voivodeship is given. Strongly represented are species associated with the communities of Festuco-Brometea and Querco-Fagetea classes (18 species per class). Comparison of the number of species classified into particular threat categories between Opole and Silesian voivodeships is presented in Figure 4. The number of locally extinct species in both regions is the same. In the Opole voivodeship more species are considered critically endangered and endangered but in the Silesian voivodeship larger numbers are representative of groups of vulnerable, near threatened and least concern species. Also for further species the available data is insufficient.

Table 1. Species not confirmed after 1945 in Strzelce Opolskie

\begin{tabular}{|c|c|c|c|c|}
\hline \multirow{2}{*}{ Species } & \multirow{2}{*}{ Record authors } & \multicolumn{2}{|c|}{ Threat category } & \multirow{2}{*}{ Syntaxon } \\
\hline & & Op & $\mathrm{Si}$ & \\
\hline Minuartia viscosa & SCHUBE, 1904 & $\mathrm{RE}$ & $\mathrm{RE}$ & Kg.- Cc. \\
\hline Pulsatilla vernalis & BRZEZAK, 1928 & $\mathrm{RE}$ & $\mathrm{RE}$ & Ses. var. \\
\hline Cyperus flavescens & SCHUBE, 1904 & $\mathrm{RE}$ & $\mathrm{CR}$ & Is.- Nan. \\
\hline Goodyera repens & SCHUBE, 1904 & $\mathrm{RE}$ & $\mathrm{CR}$ & Vac.-Pic. \\
\hline Tofieldia calyculata & SCHUBE, 1904 & $\mathrm{RE}$ & EN & Sch.- Car. \\
\hline Nonnea pulla & MICHALAK, 1976 & $\mathrm{RE}$ & VU & Fest.-Brom. \\
\hline * Ajuga chamaepitys & SCHUBE, 1904 & $\mathrm{CR}$ & $\mathrm{RE}$ & Stel. med. \\
\hline Botrychium matricariifolium & SCHUBE, 1904 & $\mathrm{CR}$ & EN & Nar.-Cal. \\
\hline Diphasiastrum complanatum & SCHUBE, 1904 & $\mathrm{CR}$ & EN & Vac-Pic. \\
\hline${ }^{*}$ Nigella arvensis & FIEK, 1881; SCHUBE, 1904 & $\mathrm{CR}$ & EN & Stel. med. \\
\hline Botrychium lunaria & SCHUBE, 1904 & $\mathrm{CR}$ & VU & Nar.-Cal. \\
\hline Cephalanthera rubra & SCHUBE, 1904 & $\mathrm{CR}$ & VU & Q.-Fag. \\
\hline Corallorhiza trifida & SCHUBE, 1904 & $\mathrm{CR}$ & VU & Vac.- Pic. \\
\hline Platanthera chlorantha & SCHUBE, 1904 & $\mathrm{CR}$ & VU & Q.-Fag. \\
\hline Viola mirabilis & SchuBE, 1904 & $\mathrm{CR}$ & VU & Q.- Fag. \\
\hline Asperula tinctoria & SCHUBE, 1904 & EN & $\mathrm{RE}$ & Fest.-Brom. \\
\hline Senecio congestus & SCHUBE, 1904 & EN & $\mathrm{RE}$ & Phrag. \\
\hline${ }^{*}$ Anagallis foemina & SCHUBE, 1904 & EN & EN & Stel. med. \\
\hline Lycopodiella inundata & SCHUBE, 1904 & EN & EN & Sch.-Car. \\
\hline Potentilla alba & SCHUBE, 1904 & EN & EN & Q.- Fag. \\
\hline Dactylorrhiza incarnata & SCHUBE, 1904 & EN & VU & Sch.- Car. \\
\hline Hypochoeris maculata & SCHUBE, 1904 & EN & VU & Fest.-Brom. \\
\hline Potentilla recta & SCHUBE, 1903 & EN & $\mathrm{VU}$ & Fest.- Brom. \\
\hline Aquilegia vulgaris & SCHUBE, 1903,1904 & EN & NT & Q.- Fag. \\
\hline Thalictrum minus & FIEK, 1881 & EN & NT & Tri-Ger.s. \\
\hline Thalictrum aquilegiifolium & Schube, 1919 & EN & NT & Bet.- Ad. \\
\hline Pulmonaria angustifolia & SCHUBE, 1904 & EN & DD & Q.- Fag. \\
\hline Scabiosa canescens & SCHUBE, 1903,1904 & VU & $\mathrm{RE}$ & Fest.-Brom. \\
\hline Vicia lathyroides & SCHALOW, 1932 & VU & EN & Kg.-Cc. \\
\hline Cephalanthera damasonium & SCHUBE, 1904 & VU & VU & Q.-Fag. \\
\hline Cephalanthera longifolia & SCHUBE, 1904 & VU & VU & Q.- Fag. \\
\hline Juncus alpino-articulatus & SCHUBE, 1904 & VU & VU & Sch.- Car. \\
\hline Ophioglossum vulgatum & SCHUBE, 1904 & VU & VU & Mol.-Ar. \\
\hline Teucrium botrys & SCHUBE, 1904 & VU & VU & Fest.-Brom. \\
\hline Veratrum lobelianum & SCHUBE, 1904 & $\mathrm{VU}$ & NT & Bet.- Ad. \\
\hline Agrimonia procera & SCHUBE, 1904 & VU & LC & Tri.-Ger.s. \\
\hline Carex pairae & SCHUBE, 1904 & VU & DD & Epil.ang. \\
\hline Carex appropinquata & SCHUBE, 1904 & NT & VU & Phrag. \\
\hline Circaea intermedia & SCHUBE, 1904 & NT & VU & Q.-Fag. \\
\hline Potamogeton alpinus & SCHUBE, 1904 & NT & VU & Pot. \\
\hline Cardamine impatiens & SCHUBE, 1904 & NT & LC & Art. vul. \\
\hline Melica uniflora & SCHUBE, 1904 & LC & VU & Q.- Fag. \\
\hline Lilium martagon & SCHUBE, 1904 & LC & NT & Q.-Fag. \\
\hline * Parietaria officinalis & SCHUBE, 1904 & - & $\mathrm{CR}$ & Art. vul. \\
\hline Astragalus cicer & SCHUBE, 1904 & - & VU & Tri.-Ger.s. \\
\hline
\end{tabular}

Key to abbreviations in Tables 1-3: * - archaeophytes; Art.vul. - Artemisietea vulgaris; Asp.rup. - Asplenietea rupestris; Bet.Ad. - Betulo-Adenostyletea; Epil.ang. - Epilobietea angustifolii; Fest.-Brom. - Festuco-Brometea; Is.-Nan. - IsöetoNanojuncetea; Kg.-Cc. - Koelerio glaucae-Corynephoretea canescentis; Mol.-Ar. - Molinio-Arrhenatheretea; Nar.-Cal. - NardoCallunetea; Phr. - Phragmitetea; Pot. - Potametea; Q.-Fag. - Querco-Fagetea; Ses.var. - Seslerietea variae; Sch.-Car. Scheuchzerio-Caricetea nigrae; Stel. med. - Stellarietea mediae; Tri.-Ger.s. - Trifolio-Geranietea sanguinei; Vac.-Pic. - VaccinioPiceetea; CR - critically endangered; DD - insufficient data; EN - endangered; LC - least concern; NT - near threatened; RE regionally extinct; VU - vulnerable; DD - data deficient; Op - Opole voivodeship; Si - Silesian voivodeship 
Table 2. Species confirmed after 1945 in Strzelce Opolskie (see abbreviation key for Table 1)

\begin{tabular}{|c|c|c|c|c|}
\hline \multirow{2}{*}{ Species } & \multirow{2}{*}{ Record authors } & \multicolumn{2}{|c|}{ Threat category } & \multirow{2}{*}{ Syntaxon } \\
\hline & & Op & $\mathrm{Si}$ & \\
\hline Gentianella cilliata & DAJDOK ET AL., 1998 & CR & VU & Fest.- Brom. \\
\hline Jovibarba sobolifera & DAJDOK ET AL., 1998 & $\mathrm{CR}$ & VU & Kg. $-C c$. \\
\hline Prunella grandiflora & SPAŁEK ET AL., 2007 & $\mathrm{CR}$ & NT & Fest.-Brom. \\
\hline * Camelina sativa & KoBIERSKI, 1974 & EN & EN & Stel. med. \\
\hline Scabiosa columbaria & KoBIERSKI, 1974 & EN & EN & Fest.-Brom. \\
\hline Galium saxatile & MICHALAK, 1963 & EN & VU & Nar.-Cal. \\
\hline Inula conyza & MICHALAK, 1981A & EN & VU & Tri.-Ger.s. \\
\hline Koeleria macrantha & SPAŁEK ET AL., 2007 & EN & VU & Fest.- Brom. \\
\hline${ }^{*}$ Bromus secalinus & FOLCIK, 2013 & EN & NT & Stel. med. \\
\hline Knautia dipsacifolia & CIACIURA \& KOWAL, 1974 & EN & DD & Tri.-Ger.s. \\
\hline Nasturtium officinale & SPALEK ET AL., 2007 & VU & EN & Phrag. \\
\hline Schoenoplectus tabernaemontani & NoWAK, 2005 & VU & EN & Phrag. \\
\hline Zannichelia palustris & KOZAK ET AL., 2005 & VU & EN & Pot. \\
\hline Cyperus fuscus & KOZAK ET AL., 2005 & VU & VU & Is.-Nan. \\
\hline Eleocharis ovata & KOZAK ET AL., 2005 & VU & VU & Is.-Nan. \\
\hline Equisetum variegatum & SPAŁEK ET AL., 2007 & VU & VU & Sch.- Car. \\
\hline Gymnocarpium dryopteris & SPAŁEK ET AL., 2007 & VU & VU & Q.- Fag. \\
\hline Melittis melisophyllum & KOBIERSKI, 1974 & VU & VU & Q.- Fag. \\
\hline Asperula cynanchica & KOBIERSKI, 1974 & VU & NT & Fest.- Brom. \\
\hline Geranium sylvaticum & FoLCIK, 2013 & VU & NT & Bet. - Ad. \\
\hline Hypericum humifusum & FOLCIK, 2013 & VU & NT & Is.- Nan. \\
\hline Melampyrum arvense & SPAŁEK ET AL., 2007 & VU & NT & Fest.-Brom. \\
\hline Nymphaea alba & FOLCIK, 2013 & VU & NT & Pot. \\
\hline Orobanche lutea & SPAŁEK ET AL., 2007 & VU & NT & Fest.-Brom. \\
\hline Viola collina & KOBIERSKI, 1974 & VU & NT & Q.- Fag. \\
\hline Geranium phaeum & FOLCIK, 2013 & VU & LC & Q.- Fag. \\
\hline Achillea pannonica & FOLCIK, 2013 & VU & DD & Fest.- Brom. \\
\hline Festuca rupicola & SPAŁEK ET AL., 2007 & $\mathrm{VU}$ & $\mathrm{DD}$ & Fest.-Brom. \\
\hline Euphorbia exigua & KOBIERSKI, 1974 & NT & VU & Stel. med. \\
\hline Anthericum ramosum & SPAŁEK ET AL., 2007 & NT & NT & Tri.-Ger.s. \\
\hline Astrantia major & KOBIERSKI, 1974 & NT & LC & Q.- Fag. \\
\hline Dactylorrhiza majalis & FOLCIK, 2013 & NT & LC & Mol.- Ar. \\
\hline Salvia pratensis & KOBIERSKI, 1974 & NT & LC & Fest.-Brom. \\
\hline Hottonia palustris & MICHALAK, 1963 & LC & VU & Pot. \\
\hline Ajuga genevensis & SPAŁEK ET AL., 2007 & $\mathrm{LC}$ & NT & Fest.- Brom. \\
\hline Actaea spicata & KoBIERSKI, 1974 & LC & LC & Q.- Fag. \\
\hline Isopyrum thalictroides & FOLCIK, 2013 & LC & LC & Q.- Fag. \\
\hline Orthilia secunda & FOLCIK, 2013 & LC & LC & Vac.- Pic. \\
\hline Polypodium vulgare & SPAŁEK ET AL., 2007 & $\mathrm{LC}$ & LC & Asp. rup. \\
\hline Carex hartmanii & FOLCIK, 2013 & $\mathrm{DD}$ & DD & Mol.- $A r$ \\
\hline Galega officinalis & FoLCIK, 2013 & - & EN & Mol.- Ar. \\
\hline Rorippa austriaca & FOLCIK, 2013 & - & VU & Mol.- Ar. \\
\hline Saxifraga granulata & FOLCIK, 2013 & - & VU & Mol.- Ar. \\
\hline *Veronica agrestis & CiaCiURA \& KoWAL, 1964 & - & VU & Stel. med. \\
\hline Anemone ranunculoides & FOLCIK, 2013 & - & NT & Q.- Fag. \\
\hline Corydalis cava & FOLCIK, 2013 & - & NT & Q.- Fag. \\
\hline Nuphar lutea. & FOLCIK, 2013 & - & NT & Pot. \\
\hline${ }^{*}$ Valerianella dentata & FoLCIK, 2013 & - & NT & Stel. med. \\
\hline Anchusa arvensis & FOLCIK, 2013 & - & LC & Art. vul. \\
\hline Ceratophyllum demersum . & FOLCIK, 2013 & - & LC & Pot. \\
\hline Gagea lutea & FOLCIK, 2013 & - & LC & Q.- Fag. \\
\hline Myriophyllum spicatum & FOLCIK, 2013 & - & LC & Pot. \\
\hline Potentilla neumanniana & FoLCIK, 2013 & - & LC & Fest.-Brom. \\
\hline Carex demissa & FOLCIK, 2013 & - & DD & Sch.-Car. \\
\hline
\end{tabular}




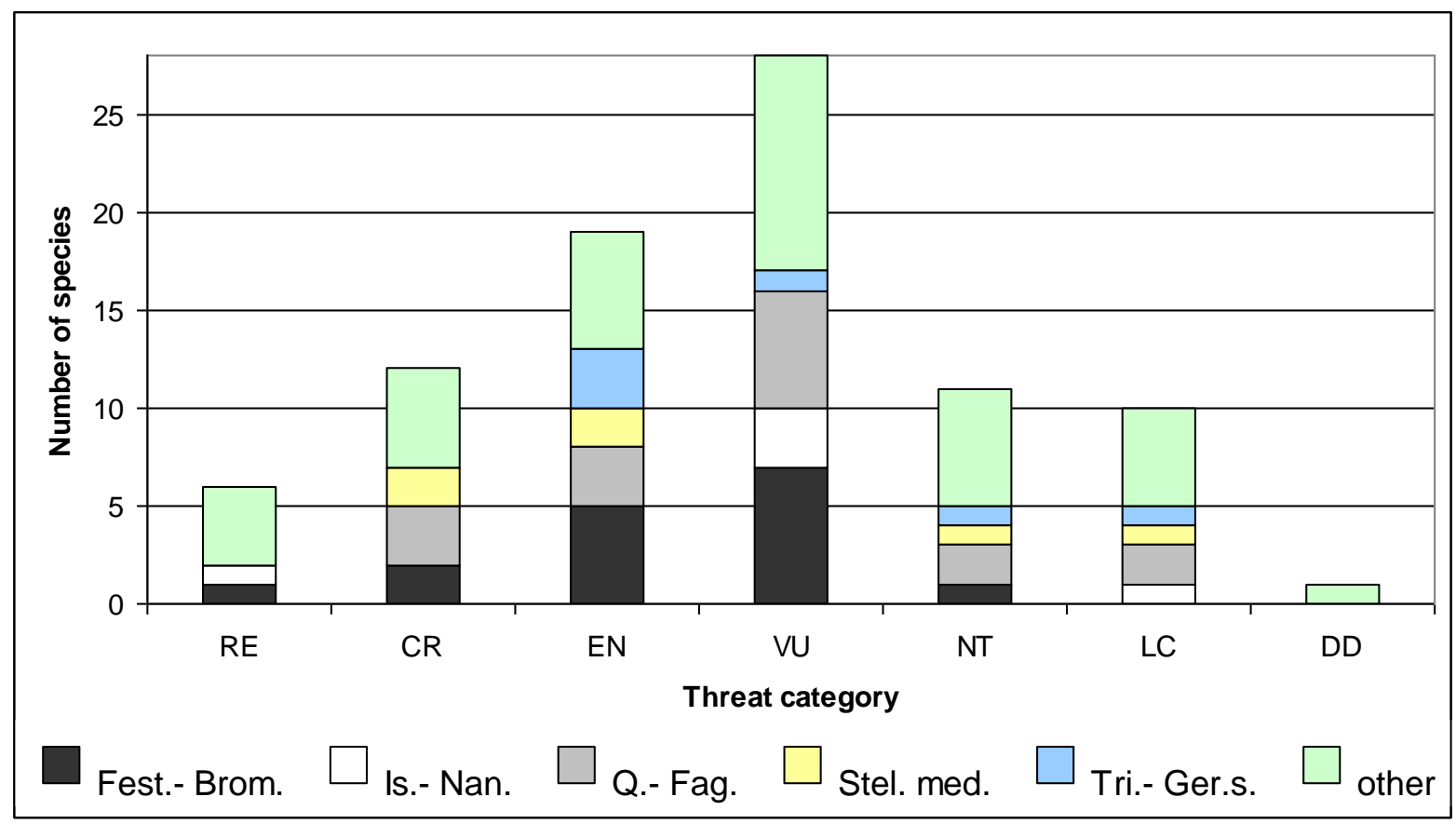

Fig. 3. Phytosociological affiliation of species assigned to a particular threat category in Opole voivodeship (see abbreviation key for Table 1)

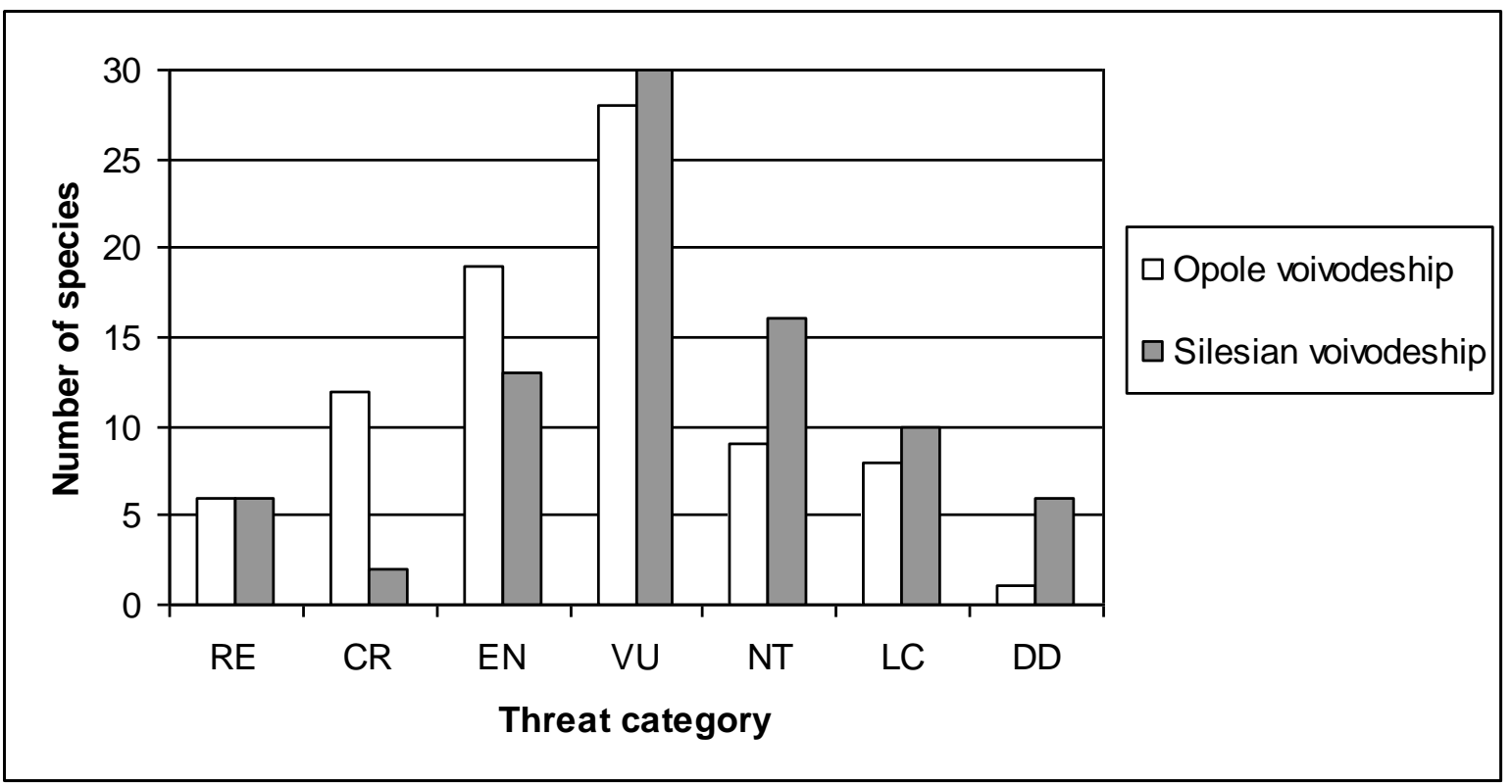

Fig. 4. Comparison between number of species recorded in Strzelce Opolskie from red lists of vascular plants of Opole and Silesian voivodeships (see abbreviations key for Table 1)

\section{Discussion}

Within the administrative boundaries of Strzelce Opolskie, 45 species, representing $7.1 \%$ of the permanently established flora were not confirmed (Tab. 1). This result is comparable with that obtained for Rybnik in another study (42 species unconfirmed after 1945, i.e. 4\% of permanently established flora - URBISZ \& URBISZ, 2003). A nearly threefold larger number of species have not been confirmed in Poznań (124 unconfirmed after 1951 which is $11.6 \%$ of total flora - JACKOWIAK, 1990). This is mainly because of the larger area that this city occupies. Some interesting analyses of extinction rate in worldwide urban environments have been published (HAHS ET AL., 2009; DUNCAN ET AL., 2011). Authors indicate the number of extinct and extant species together with a length of investigations of flora of the examined cities (Tab. 3).

Among the extinct and endangered vascular plant species in Opole voivodeship, 18 species are included in the "Red List of Vascular Plants of Poland" (MIREK ET AL., 2006). Vulnerable species (category V) are represented by Ajuga chamaepitys, Anagallis foemina, Asperula tinctoria, Botrychium lunaria, $B$. matricariifolium, Bromus secalinus, Cephalanthera 
damasonium, C. longifolia, C. rubra, Corallorhiza trifida, Cyperus flavescens, Eleocharis ovata, Lycopodiella inundata, Ophioglossum vulgatum and Potamogeton alpinus. A species in danger of extinction in isolated localities (category [V]) is Tofieldia calyculata. Becoming extinct and critically endangered at a national scale (category E) is Botrychium matricariifolium. Goodyera repens is considered critically endangered in isolated localities (category [E]). The most numerous endangered species in Poland are orchids and pteridophytes (MIREK ET AL., 2006). The threat of these groups is mainly in situations with decisive modifications or disappearance of characteristic habitats where there is specific adaptation biology.

Table 3. The number of native species that became locally extinct in the study period and the number of native species that persisted (extant) in the given cities (see abbreviation key for Table 1)

\begin{tabular}{|c|c|c|c|c|c|}
\hline City & $\begin{array}{c}\text { Locally extinct } \\
\text { species }\end{array}$ & $\begin{array}{c}\text { Extant native } \\
\text { species }\end{array}$ & Species loss \% & Study length & Source \\
\hline Adelaide & 81 & 964 & 8.4 & 166 & TAIT ET AL., 2005 \\
\hline Auckland & 80 & 293 & 27.3 & 114 & DunCAN \& YounG, 2000 \\
\hline Singapore & 598 & 1578 & 37.9 & c. 100 & CHONG ET AL., 2009 \\
\hline New York & 401 & 1159 & 34.5 & 207 & CoRLETT ET AL., 2000 \\
\hline Worcester, MA & 174 & 644 & 27 & c. 100 & BERTIN, 2002 \\
\hline
\end{tabular}

The extinct and endangered species of the Strzelce Opolskie vascular plant flora are most commonly associated with communities belonging to Festuco-Brometea and Querco-Fagetea (especially Cephalanthero-Fagenion suballiance) classes. In the study area these phytocoenoses have almost completely disappeared. The neglect, change and abandonment of a whole array of traditional practices is the main cause of the disappearance of calcareous grasslands. Some of them have probably been overgrown by trees and shrubs which has a dramatic effect on specific species combinations. Calcareous grasslands and beech forests of Strzelce Opolskie could have originally constituted a large complex with phytocoenoses extant within the Chełm Rigde centre, where some nature reserves have been established (e.g. Ligota Dolna - 1959, Góra św. Anny - 1972, Boże Oko - 1997, Biesiec - 2001 and others). Forest communities, especially the so-called beech-orchid forests, have probably undergone a complete deforestation and their habitats are now occupied by pine monocultures and arable land.

In comparison with the Silesian voivodeship, in the Opole region more species are considered critically endangered and endangered but less are classified as vulnerable, near threatened or of least concern. Among the species analysed, 23 $(27.7 \%)$ belong to the same threat category, 16 $(19.3 \%)$ are at higher risk in the Silesian and 44 $(53 \%)$ in the Opole voivodeship.

In Opole voivodeship 16 species are not included in the red list of vascular plant species, but they are listed in a similar work compiled for the neighboring Silesian voivodeship (Tab. 3.) Due to the short distance and the lack of any ecological barriers between these regions, it can be concluded with high probability that this group of species had been overlooked and some of them have not been precisely recognised in the face of taxonomic difficulties.

The number of native species and the so-called archaeophytes (i.e. naturalised alien plant species introduced before 1500) found in urban areas is clearly declining. Species considered probably extinct are only a small percentage of the spontaneous town flora. However, these are approximate values which are highly influenced by the particular impact on land use within the town area and the intensity of floristic research.

Within administrative boundaries of Strzelce Opolskie, the only Miejski Park is under the conservator's protection and there are few individual trees protected due to their age or size. Another several taxa protected by Polish Nature Conservation Act can be found. The local authorities should take a positive action in restoring native vegetation in the landscape of the town. There is need to improve management of the remaining native vegetation with emphasis on spatial management, leading to maximise proportion of native species and minimise the isolation of rare and endangered plant species populations. It is worth protecting some small populations of plants in urban areas. These populations are always destined for rapid extinction.

National environmental protection policy should not be only focused on the particular, natural types of plant communities (e.g. alpine grasslands) or groups of species (e.g. orchids). The species loss in urban areas should be examined more precisely in terms of the rate, environmental determinants and human practices leading to improvement of the biodiversity of city flora. 


\section{References}

Bertin R. I. 2002. Losses of native plant species from Worcester, Massachusetts. Rhodora, 104: 325-349.

Briggs D. 2010. Plant microevolution in human-influenced ecosystems. Cambridge Univ. Press, Cambridge.

Brzezak W. 1928. Pflanzenwelt im Kreise Beuthen. Unsere Heimat Beil. Oberschl. Rundschau.

Celiński F., Ludera F., Rostański K., Sendek A., Wika S. 1974-1975. Nowe stanowiska rzadkich roślin naczyniowych na Górnym Śląsku i terenach przyległych. Cz. I i II. Zesz. Przyr. OTPN, 14-15: 11-31.

Chong K. Y., Tan H. T. W., Corlett R. T. 2009. A checklist of the total vascular plant flora of Singapore: native, naturalised and cultivated species. Raffles Museum of Biodiversity Research, Singapore.

Ciaciura M., Kowal T. 1964. Nowe stanowiska roślin rzadkich na Śląsku. Zesz. Przyr. OTPN, 4: 125-134.

Ciaciura M., Kowal T., Serwatka J. 1962. Materiały zielnikowe do flory Śląska. Kwart. Opolski. Zesz. Przyr., 2: 91-107.

Corlett R. T., Xing F., Ng S. C., Chau K. C., Wong, L. M. Y. 2000. Hong Kong vascular plants: distribution and status. Memoirs of the Hong Kong Natural History Society, 23: 1-157.

Dajdok Z., Kącki Z., Nowak A., Nowak S., Spałek K. 1998. Atlas rozmieszczenia roślin naczyniowych prawnie chronionych $w$ województwie opolskim. Uniw. Opolski, Opole.

Duncan R. P., Clemants S. E., Hahs A. K. McDonnell M. J., McCarthy, M. A., Vesk P. A., Corlett R. T., Norton B. A., Thompson K. Schwartz M. W., Williams N. S. G. 2011. Plant traits and extinction in urban areas: a meta-analysis of 11 cities. Global Ecol. Biogeogr. 20: 509-519.

Duncan R. P., Young J. R. 2000. Determinants of plant extinction and rarity 145 years after European settlement of Auckland, New Zealand. Ecology, 81: 3048-3061.

Fiek E. 1881. Flora von Schlesien preussischen und österreichischen Antheils. J. U. Kerns Verl. Breslau.

Folcik Ł. 2013. Flora roślin naczyniowych miasta Strzelce Opolskie. WBiOŚ, Uniw. Śl., Katowice [manuskrypt].

Główny Urząd Statystyczny 2012. Statistical Yearbook of The Republic of Poland, http://www.stat.gov.pl/gus/ dostęp on-line 30.01.2013.

Hahs, A. K., McDonnell, M. J., McCarthy, M. A., Vesk, P. A., Corlett, R. T., Norton, B. A., Clemants S. E., Duncan R. P., Thompson K., Schwartz M. W., Williams N. S. G. 2009. A global synthesis of plant exctinction rates in urban areas. Ecology Letters, 12(11): 1165-1173.

Jackowiak B. 1990. Antropogeniczne przemiany flory roślin naczyniowych Poznania. UAM Poznań. Seria Biol., nr 42.

Kobierski L. 1974. Rośliny naczyniowe Garbu Tarnogórskiego na Wyżynie Śląskiej. Roczn. Muz. Górnośl. w Bytomiu, Ser. Przyr., 8: 1-189.

Kondracki J. 1988. Geografia fizyczna Polski. PWN Warszawa.

Kozak M., Nowak A., Olszanowska-Kuńka K. 2005. Materials to the distribution of threatened vascular plants in the Opole Silesia. Nature Journal, 38: 25-55.

Matuszkiewicz W. 2008. Przewodnik do oznaczania zbiorowisk roślinnych Polski. Wyd. Nauk. PWN, Warszawa.

Mądalski J., Kowal T., Kuźniewski E., Serwatka G., Ciaciura M. 1963. Materiały do rozmieszczenia roślin naczyniowych na Śląsku zebrane w 1961r. Zesz. Przyr. OTPN, 3: 65-138.

Michalak S. 1963. Materiały florystyczne z Opolszczyzny za rok 1961. Zesz. Przyr. OTPN, 3: 139-149.

Michalak S. 1976. Nowe stanowiska rzadszych roślin synantropijnych w woj. opolskim. Zesz. Przyr. OTPN, 16: 33-49.

Michalak S. 1981a. Niektóre gatunki flory synantropijnej województwa opolskiego. Część 4. Fragm. Flor. Geobot., 27(3): 371-374.
Michalak S. 1981b. Lista efemerofitów Opolszczyzny. Zesz. Przyr. OTPN, 14-15: 3-10.

Mirek Z., Piękoś-Mirek H., Zając A., Zając M. 2002. Flowering plants and pteridophytes of Poland. A checklist. [Krytyczna lista roślin naczyniowych Polski]. W. Szafer Inst. of Botany, Polish Academy of Sciences, Kraków.

Mirek, Z., Zarzycki, K., Wojewoda, W., Szeląg, Z. (eds). 2006. Red List of Plants and Fungi in Poland. W. Szafer Inst. of Botany, Polish Academy of Sciences, Kraków.

Nowak A. 2005. Występowanie rzadkich i ginących roślin naczyniowych na siedliskach antropogenicznych Śląska Opolskiego. Fragm. Flor. Geobot. Polonica, 32(2): 58-67.

Nowak A. 2011a. Rośliny ustępujące i rzadkie w siedliskach antropogenicznych Śląska. Część I. Katalog stanowisk oraz charakterystyka gatunków. Wyd. Uniw. Opolskiego, Studia i Monografie, 454.

Nowak A. 2011b. Rośliny ustępujące i rzadkie w siedliskach antropogenicznych Śląska. Część II. Studium florystycznoekologiczne. Wyd. Uniw. Opolskiego, Studia i Monografie, 455.

Nowak A., Nowak S., Spałek K. 2008. Red list of vascular plants of Opole Province - 2008. Nature Journal, 41: 141-158.

Nowak A., Spałek K. (eds.). 2002. Czerwona Księga Roślin Województwa Opolskiego. Opol. Tow. Przyj. Nauk, Opole.

Nowak S., Nowak A., Jermaczek A., 2013. Zagrożone chwasty polne Opolszczyzny i ich ochrona. Wyd. Klubu Przyrod., Świebodzin.

Parusel J. B., Urbisz An. (eds.). 2012. Czerwona lista roślin naczyniowych województwa śląskiego. The red list of vascular plants of Silesian voivodeship. [in:] Strategia ochrony województwa śląskiego na lata 2011-2030. Raport o stanie przyrody województwa śląskiego. Raporty i Opinie, 6: 105-176.

Pawlak W. 1997. Atlas Śląska Dolnego i Opolskiego. Pracownia Atlasu Dolnego Śląska, Uniw. Wrocławski.

Schalow E. 1931. Ergebnisse der schlesischen Phanerogamenforschung im Jahre 1930. Jahresber. Schles. Ges. Vaterl. Cult., 103: 116-132.

Schalow E. 1932. Ergebnisse der Durchforschung der schlesischen Gefässpflanzenwelt im Jahre 1931. Jahr. - Ber. Schles. Gesell. vaterl. Cult., 104: 92-112.

Schube T. 1903. Die Verbreitung der Gefässpflanzen in Schlesien preussischen und österreichischen Anteils. Breslau.

Schube T. 1904. Flora von Schlesien preussischen und ostereichischen Antheils. Verl. Wilh. Gottl. Korn. Breslau.

Schube T. 1911-1925. Ergebnisse der Durchforschung der Schlesinchen Gefässpflanzenwelt in Jahre 1911, 1912, 1915, 1916, 1917, 1919 i 1925. Jahres-Ber. d. Schles. Gesell. f. vaterl. Cultur.

Sendek A. 1965. Materiały florystyczne do rozmieszczenia roślin naczyniowych na Śląsku zebrane w latach 19631964. Zesz. Przyr. OTPN, 5: 109-128.

Sendek A. 1971. Nowe stanowiska rzadkich gatunków roślin na Śląsku, zebranych w latach 1968 i 1969. Zesz. Przyr. OTPN, 11: 51-56.

Sendek A. 1989. Gatunki Caucalido-Scandicetum (Libbert 1930) R.Tx. 1937 na Wyżynie Śląskiej. Zesz. Przyr. OTPN, 27: 37-43.

Smoleń S. 1998. Strzelce Opolskie znane i nieznane. Urz. Miasta i Gminy, Strzelce Opolskie.

Spałek K., Badora K., Kuńka A., Nowak A. 2007. Inwentaryzacja i waloryzacja przyrodnicza gminy Strzelce Opolskie. BIOPLAN, Krasiejów.

Stenzel G. 1876. Gefasskryptogamen. [in:] Cohn F. (red.) Kryptogamen-Flora von Schlesien. I. U. Kern's Verl., Breslau 1: 1-26. 
Szotkowski P. 1969. Stanowiska rzadkich gatunków roślin z Opolszczyzny, zebranych w latach 1965-1967. Zesz. Przyr. OTPN, 9: 21-26.

Szymankiewicz W. 1994. Takie sq Strzelce Opolskie. Wyd. Inst. Śl., Opole.

Tait C.J., Daniels C.B., Hill R.S. 2005. Changes in species assemblages within the Adelaide Metropolitan Area, Australia. Ecological Applications, 15: 346-359.

Urbisz An., Urbisz Al. 2003. Antropogeniczne przemiany flory roślin naczyniowych miasta Rybnik. [in:] Korczyński M. (eds.) Flora miast., Kujaw.-Pomor. Centr. Eduk. Ekol., PTB, Oddz. w Bydgoszczy: 59-65.

Urbisz An., Urbisz Al. 2009. Vascular plants recorded for the last time before 1945 year in the Silesian Uplands (Southern Poland). [in:] The role of geobotany in biodiversity conservation. Holeksa J., Babczyńska-Sendek B., Wika S. (eds.). Univ. of Silesia, Katowice: 253-258.

Wimmer F. 1857. Flora von Schlesien. F. Hirt's Verl., Breslau.

Wimmer F., Grabowski H. 1827. Flora Silesiae I. Vratislaviae.

Wimmer F., Grabowski H. 1829: Flora Silesiae II. Vratislaviae.

Zając A., Zając M. 2001. Distribution Atlas of Vascular Plants in Poland. Laboratory of Computer Chorology, Inst. of Botany, Jagiellonian Univ., Kraków.

Zarzycki K. 1986. Lista wymierających i zagrożonych roślin naczyniowych Polski. [in:] Zarzycki K., Wojewoda K. (eds.)
Lista roślin wymierajacych i zagrożonych $w$ Polsce. PWN, Warszawa: 11-27.

Zarzycki K., Kaźmierczakowa R. (eds.). 1993. Polska czerwona księga roślin. Paprotniki i rośliny kwiatowe. Kraków: Inst. Botaniki im. W. Szafera PAN, Kraków.

Zarzycki K., Kaźmierczakowa R. (eds.). 2001. Polska czerwona księga roślin. Paprotniki i rośliny kwiatowe. Kraków: Inst. Botaniki im. W. Szafera PAN, Kraków.

Zarzycki K., Mirek Z. 2006. Red list of plants and fungi in Poland. Kraków: Inst. Botaniki im. W. Szafera PAN, Kraków.

Zarzycki K., Szeląg Z. 1992. Czerwona lista roślin naczyniowych zagrożonych w Polsce. [in:] Zarzycki K., Wojewoda K. (eds.) Lista roślin zagrożonych w Polsce. PAN, Kraków: 87-98.

Zarzycki K., Trzcińska-Tacik H., Różański W., Szeląg Z., Wołek J., Korzeniak U. 2002. Ecological Indicator Values of Vascular P'lants of Poland. Ekologiczne liczby wskaźnikowe roślin naczyniowych Polski. W. Szafer Inst. of Botany, Polish Academy of Sciences, Kraków.

Zarzycki K., Wojewoda W., Heinrich Z. (eds.). 1992. Lista roślin zagrożonych $w$ Polsce. II wyd., Inst. Bot. im. W. Szafera PAN, Kraków: 87-98. 